\title{
Pregnant women's awareness of sensitivity to cold (hiesho) and body temperature observational study: A comparison of Japanese and Brazilian women
}

Sachiyo Nakamura ${ }^{1 * \dagger}$, Sueli MT Ichisato ${ }^{2 \dagger}$, Shigeko Horiuchi ${ }^{3+}$, Taeko Mori ${ }^{4 \dagger}$ and Masako Momoi ${ }^{5+}$

\begin{abstract}
Background: Sensitivity to cold (hiesho) is a serious health problem in Japan, yet it is minimally understood within Western cultures. The purpose of this study was to clarify the divergence between pregnant Japanese woman living in Japan and pregnant Brazilian women living in Brazil in awareness of hiesho and differences between core body and peripheral temperatures.
\end{abstract}

Methods: The subjects of this study were 230 pregnant Japanese women living in Japan and 200 pregnant Brazilian women living in Brazil. Data was collected in June/July and November 2005 in Japan and from October 2007 to February 2008 in Brazil. The survey methods consisted of measurement of deep body temperatures and questionnaires.

Results: $67.0 \%$ of Japanese women and $57.0 \%$ of Brazilian women were aware of hiesho, which showed a significant difference between the Japanese and Brazilian women $(p=0.034)$. The difference between forehead and sole temperatures was $2.0^{\circ} \mathrm{C}$ among Japanese and $2.8^{\circ} \mathrm{C}$ among Brazilians in June-July $(p=0.01)$. But in November the difference between those temperatures was $5.2^{\circ} \mathrm{C}$ among Japanese and $2.8^{\circ} \mathrm{C}$ among Brazilians $(p<0.001)$.

Conclusions: There are differences between Japanese and Brazilians both in awareness of hiesho and in body temperatures.

\section{Background}

Hiesho, the Japanese word for "sensitivity to cold," is a serious health problem in Japan, adversely affecting over $50 \%$ of Japanese women [1-4]. Oriental medicine holds that "hiesho lies at the root of all ailments," causing all types of illnesses, and that it is a condition that should be treated [5]. In the research of Miyamoto et al., Japanese women experienced cold hands and feet even during the summer, and this phenomenon was reported to be significantly higher among those who were aware of hiesho[6]. Despite the fact that hiesho is a well-known concept in Japan and throughout Asia, even major medical textbooks in the West make no mention of hiesho $[7,8]$.

\footnotetext{
* Correspondence: nakamura@sfc.keio.ac.jp

+ Contributed equally

${ }^{1}$ Keio University,4411 Endo, Fujisawa, Kanagawa 252-8330, Japan

Full list of author information is available at the end of the article
}

Nakamura [9] used Rodger's concept analysis to clarify the definition of hiesho, and three attributes of the concept "hiesho" were identified. Accordingly, hiesho was defined as a state where there exists a difference between core body temperature and peripheral temperature, and slow recovery of the peripheral temperature in a warm environment, with the subject usually having an awareness of hiesho. However, most of the articles dealing with hiesho she found for the analysis were written by Japanese researchers, and it was suggested that the concept "hiesho" did not exist in the West. As a result of Nakamura's study on Japanese pregnant women [4], it was found that hiesho was related to minor health problems and the daily activities of Japanese women.

On the other hand, the study by Nakamura et al. [10] on Brazilian pregnant women did not recognize any relationship between hiesho and daily activities, even
C Biomed Central 
though more than $50 \%$ of Brazilian women were aware of hiesho. In other words, they did not feel hiesho as discomfort and it was suggested that even increased awareness of hiesho did not worsen minor health problems related to hiesho.

From the above, it is understood that there is a big difference between Japanese and Brazilians as far as hiesho is concerned.

This study was conducted on Japanese pregnant women living in Japan and Brazilian pregnant women living in Brazil for elucidating the divergence between women in these two countries in awareness of hiesho and differences between core body and peripheral temperatures.

The author believes this research will be helpful in explaining and establishing the concept of hiesho, and thus contribute to an important area of cultural anthropological study of Japanese people.

The operational definition of terms used in this study is as follows. Core body temperature: Temperature of the internal deep tissues less affected by ambient environmental temperature [11]. Hiesho (sensitivity to cold): A medical condition characterized by differences between core body temperature and peripheral temperature where the peripheral temperature is slow to increase, even in warm ambient temperatures. In many cases, it is accompanied by an awareness of hiesho [9]. Awareness of hiesho: Determined by the answer to the question "Are you sensitive to cold?" in the Scale for Determining Hiesho (Terasawa) [3].

\section{Methods}

\section{Subjects of study}

The study was carried out among 230 Japanese women (Nakamura 2008) and 200 Brazilian women (Nakamura et al. 2010) who agreed to participate and who met the following criteria at the time of recruitment: 1) in the 20th or later week of pregnancy; 2) no complications affecting the pregnancy or body temperature (endocrine disorders, autonomic nervous system disorders, hypertension, heart disease, liver disease, kidney disease, psychiatric illness, etc.); and 3) normal progress of pregnancy.

Concerning 1), there is a physiological rise in body temperature until the fourth month of pregnancy, believed to be caused by the effects of progesterone coming from the corpus luteum, which increases metabolism. After the fourth month, body temperature gradually drops, returning to a normal level around the sixth to seventh month and remaining at that level until delivery [12]. Therefore, this research targeted subjects past the 20th week of pregnancy, when body temperature has stabilized.

This study is a reanalysis of part of previously published data. They were reanalyzed to meet the purpose of this study $[4,10]$.

\section{Study Setting}

Japan has four distinct seasons, whereas seasonal variations in Brazil less pronounced. This study compared Japanese and Brazilian pregnant women by dividing the research period in Japan between summer and late autumn.

In Japan, data was collected in June-July and November 2005, at a maternity clinic in Tokyo. The study period in Brazil was from October 2007 to February 2008, with data collected from one university hospital and four regional health centers in Maringa, Parana State.

\section{Data Collection}

To ensure reliability and appropriateness, care was taken to use consistent data collection methods throughout. To measure deep body temperatures, probes were attached to the middle of the subjects' forehead and the middle of the sole of the foot. Miura, using thermography to measure surface skin temperature, reported that acclimatization time took 10 minutes [13]. In this study, taking the ambient temperature into consideration, the women's temperatures were measured after they had spent at least 20 minutes in a measuring room where a constant temperature was maintained. After their temperatures had been measured, the women were given questionnaires to complete and hand back to the researcher.

\section{Instrument (Deep Body Temperature)}

A Japanese-made Core-Temp ${ }^{\mathbb{B}}$ CTM-205, Terumo Corp., Tokyo, Japan, a reliable and minimally invasive thermometer using zero-heat-flow technology, was used for measuring deep body temperatures from surface skin. Deep body temperatures were measured on the forehead and the sole of the foot, to obtain temperature differences between these two parts of the body. Tsuji reported that forehead and abdomen temperatures correspond to deep body temperature called core body temperature, whereas temperatures of the palm of the hand and the sole of the foot are peripheral temperatures and correspond to the shell temperature. Forehead temperature is believed to reflect brain temperature, and Tsuji noted that it was close to pulmonary artery blood temperature $[14,15]$. This indicates that among deep body temperatures, forehead temperature is close to the core body temperature, and that the lowest temperature is the sole temperature. Therefore, the forehead temperature measured in this study reliably reflects core body temperature. Yamazaki [16] reported that there were no temperature differences between the left and right sides of the body; subjects' temperatures were measured on either side of the body where a probe could be effectively attached. 


\section{Awareness of hiesho}

Subjects were asked to fill in Terasawa [3]'s questionnaire to determine their awareness of hiesho. According to a preceding study, "awareness of hiesho" and the answer to the question "Are you sensitive to cold?" in the Scale for Determining Hiesho (Terasawa) coincided for $80.0 \%$ of Japanese and $79.9 \%$ of Brazilians, showing significant correlation. In other words, it was possible to determine awareness of hiesho based on one item in the scale whether the individual believed that she was or was not sensitive to cold.

Concerning the survey in Brazil, in order to avoid misunderstandings caused by language differences, a specialist in Portuguese and Japanese was asked to translate the questionnaire and explanatory documentation into Portuguese. In addition, a different specialist carried out the back-translation. Thus, accuracy was verified.

\section{Ethical considerations}

The study in Japan was conducted with the approval of the Ethics Review Committee of St. Luke's College of Nursing (05-012). In Brazil, the research representative entered into an international cooperation agreement with the university to which research collaborators belong (Parana State official gazette no. 7664). The Ethics Review Committee of St. Luke's College of Nursing (07-029) and Maringa University, Parana State (PARECER n.298/2007), and the Ethics Examination Committee of the National Ethics Council (PARECER n. 54/2008) granted approval.

Individuals willing to cooperate in this research project were given both written and oral explanations of the research, and when they agreed to participate, were asked to sign an informed consent form. If they decided that they wanted to drop out of the study after giving their consent, they were asked to sign a form saying they would no longer participate. Due care was paid to ethical considerations, in order to protect the human rights of the subjects.

\section{Data Analyses}

Differences in temperatures at the forehead and on the sole of the foot were compared, using a t test. In all cases, standard deviation, 95\% confidence interval (CI value), degrees of freedom and $\mathrm{p}$ values were calculated, with a 5\% significance level. Statistics software SPSS Statistics 19.0 was used for statistical analysis.

BMI values $\left(\mathrm{kg} / \mathrm{m}^{2}\right)$ were classified according to the WHO definition as follows: underweight $<18.50$, normal range 18.50-24.99, overweight $\geq 25.00$, and obese $\geq 30.00$ [17].

\section{Results}

The subjects of this study were 235 pregnant Japanese women living in Japan and 206 pregnant Brazilian women living in Brazil. Out of the subjects, five Japanese and six Brazilian women withdrew prior to the study. Ultimately, 230 Japanese and 200 Brazilians became the subjects of the analysis.

Among the Japanese subjects, 130 women were surveyed in June-July and 100 in November, for a total of 230. The total number of Brazilian women surveyed was 200.

Characteristics of all subjects were compared as shown in Table 1.

The average age of the Japanese was 31.8 years (SD4.3), older than the Brazilians' average of 26.2 years (SD5.7) ( $\mathrm{p}<0.001$ ). Regarding obesity of Japanese based on average BMI $\left(\mathrm{kg} / \mathrm{m}^{2}\right)$, "normal range" accounted for the largest portion: $60.9 \%$ (140 persons), followed by "underweight: $15.2 \%$ (35 persons), while among Brazilians, "obese" accounted for $52.5 \%$ (105 persons), followed by "normal range" for $23.0 \%$ (46 persons). In other words, Japanese women were thinner than Brazilian women $(p<0.001)$.

\section{Comparison of subjects' backgrounds in hiesho in pregnant women (Table 2)}

Characteristics of pregnant women with awareness of hiesho were compared.

The average age of the Japanese was 31.8 years (SD4.3), older than the Brazilians' average of 25.8 years (SD5.5) ( $\mathrm{p}<0.001)$. Regarding obesity of Japanese based on average BMI $\left(\mathrm{kg} / \mathrm{m}^{2}\right)$, "normal range" accounted for the largest portion: $65.6 \%$ (101 persons), followed by "underweight" $17.5 \%$ (27 persons), while among Brazilians, "obese" accounted for $48.2 \%$ (55 persons), followed by "normal range" for $30.7 \%$ (35 persons). In other words, Japanese women with hiesho were thinner than Brazilian women with hiesho $(\mathrm{p}=0.001)$. Ninety Japanese were primiparae (54.8\%), while among Brazilians with hiesho 70 were multiparae $(61.4 \%)(\mathrm{p}=0.001)$.

\section{Comparison of Japanese and Brazilian pregnant women in awareness of hiesho (Table 3)}

$67.0 \%$ of Japanese women (154 persons) and $57.0 \%$ of Brazilian women (114 persons) were aware of hiesho. In other words, $33.0 \%$ of Japanese women (76 persons) and $43.0 \%$ of Brazilian women (86 persons) were not aware of hiesho and the concordance rate was $80.9 \%$. Results of a chi-square test also showed a significant difference between the Japanese and the Brazilian women $(\mathrm{p}=0.034)$.

In short, Japanese women were significantly more aware of hiesho than Brazilian women.

\section{Comparison of differences between forehead and sole temperatures among women with awareness of hiesho} The deep body temperatures of Japanese and Brazilian pregnant women with awareness of hiesho were compared. The Japanese subjects $(n=88)$ were measured in 
Table 1 Demographic Characteristics of Participants

\begin{tabular}{|c|c|c|c|c|c|}
\hline & Japanese $(n=230)$ & Brazilia & $=200)$ & & \\
\hline & Mean (SD)/n (\%) & Mean (SD)/n (\%) & $\mathrm{t}$ value $/ \chi 2$ value & df & $\mathrm{p}$ value \\
\hline Age & $31.8(4.3)$ & $26.2(5.7)$ & -11.15 & 373.79 & $<0.001^{*}$ \\
\hline Gestational age(weeks) & 28.5(5.9) & $29.3(5.8)$ & 1.40 & 428 & 0.16 \\
\hline Elapsed time after meal intake(hour) & $3.0(2.6)$ & $3.1(3.1)$ & 4.42 & 422.53 & $<0.001^{*}$ \\
\hline Body height(cm) & $159.1(5.2)$ & $161.3(6.3)$ & 3.93 & 386.06 & $<0.001^{*}$ \\
\hline Body weight(kg) & $57.3(7.8)$ & $70.97(13.1)$ & 12.92 & 315.00 & $<0.001^{*}$ \\
\hline \multicolumn{6}{|l|}{ BMI Mean (SD) body mass index (kg/m2) } \\
\hline Underweight & $35.0(15.2)$ & $8.0(4.0)$ & 119.6 & 3 & $<0.001^{*}$ \\
\hline Normal range & 140.0(60.9) & $46.0(23.0)$ & & & \\
\hline Overweight & $34.0(14.8)$ & $41.0(20.5)$ & & & \\
\hline Obese & 21.0(9.1) & 105.0(52.5) & & & \\
\hline \multicolumn{6}{|l|}{ Parity } \\
\hline Primipara & 132.0(57.4) & $73.0(36.5)$ & 18.72 & 1 & $<0.001^{*}$ \\
\hline Pluripara & $98.0(42.6)$ & $127.0(63.5)$ & & & \\
\hline \multicolumn{6}{|l|}{ Occupation } \\
\hline Homemaker & $169.0(73.5)$ & $72.0(36.0)$ & 109.28 & 2 & $<0.001^{*}$ \\
\hline Company worker & $38.0(16.5)$ & $128.0(64.0)$ & & & \\
\hline Other & $23.0(10.0)$ & $0.0(0)$ & & & \\
\hline
\end{tabular}

1) Age,Gestational age(weeks),Elapsed time after meal intake(hour),Body height(cm),Body weight(kg):t-test/Mean (SD), t-value

2) MI,Parity,Occupation:chi-square test,n (\%), $\chi 2$-value

June-July and the Brazilians $(\mathrm{n}=114)$ in October-February (Table 4). Average outdoor temperature at the time of the study in Japan was $25.0^{\circ} \mathrm{C}$ and in Brazil $23.5^{\circ} \mathrm{C}$.

For Japanese in June-July, the mean forehead temperature of women with awareness of hiesho was $36.4^{\circ} \mathrm{C}$, compared to $36.3^{\circ} \mathrm{C}$ for Brazilian women, which was not a significant difference $(\mathrm{p}=0.8)$. The mean sole temperature of Japanese women was $34.4^{\circ} \mathrm{C}$, compared to $33.5^{\circ} \mathrm{C}$ for Brazilian women, showing a significant difference $(p=0.004)$. The mean difference between forehead and sole temperatures among Brazilian women was $2.8^{\circ} \mathrm{C}$, significantly larger than the $2.0^{\circ} \mathrm{C}$ for Japanese women $(95 \%$ CI, 0.27 to $1.49 ; \mathrm{p}=0.01$ ).

Additionally, data collected on Brazilians $(\mathrm{n}=114)$ in October-February was compared with that of Japanese $(\mathrm{n}=66)$ monitored in November (Table 5). As a result,

Table 2 Demographic Characteristics of Participants by Awareness of Sensitivity to Cold (Hiesho)

\begin{tabular}{|c|c|c|c|c|c|}
\hline \multicolumn{6}{|c|}{ Awareness of hiesho $(\mathrm{N}=268)$} \\
\hline & Japanese $(n=154)$ & Brazilian $(n=114)$ & & & \\
\hline & Mean (SD)/n (\%) & Mean (SD)/n (\%) & $\mathrm{t}$ value $/ \chi 2$ value & df & $\mathrm{p}$ value \\
\hline Age & $31.8(4.3)$ & $25.8(5.5)$ & 9.76 & 206.56 & $<0.001^{*}$ \\
\hline Body height(cm) & $158.7(5.4)$ & $161.0(6.2)$ & -3.32 & 266 & $0.001^{*}$ \\
\hline Body weight(kg) & $55.9(6.9)$ & $68.9(12.4)$ & -10.11 & 266 & $<0.001^{*}$ \\
\hline \multicolumn{6}{|l|}{ BMI Mean (SD) body mass index ( $\mathrm{kg} / \mathrm{m} 2)$} \\
\hline Underweight & $27.0(17.5)$ & $6.0(5.3)$ & & & \\
\hline Normal range & 101.0(65.6) & $35.0(30.7)$ & 72.31 & 3 & $0.001^{*}$ \\
\hline Overweight & $16.0(10.4)$ & 18.0(15.8) & & & \\
\hline Obese & $10.0(6.5)$ & $55.0(48.2)$ & & & \\
\hline \multicolumn{6}{|l|}{ Parity } \\
\hline Primipara & $90.0(54.8)$ & $44.0(38.6)$ & 10.32 & 1 & $0.001^{*}$ \\
\hline Pluripara & $64.0(45.2)$ & $70.0(61.4)$ & & & \\
\hline \multicolumn{6}{|l|}{ Occupation } \\
\hline Homemaker & $112.0(72.7)$ & $36.0(31.6)$ & 76.77 & 2 & $0.001^{*}$ \\
\hline Company worker & $26.0(16.9)$ & $78.0(68.4)$ & & & \\
\hline Other & $7.0(9.4)$ & $0.0(0)$ & & & \\
\hline
\end{tabular}

1)Age,Body height(cm),Body weight(kg):t-test/Mean (SD), t-value

2)BMI,Parity,Occupation:chi-square test,n (\%), $\chi 2$-value 
Table 3 Awareness of hiesho : comparison between Japanese and Brazilians

\begin{tabular}{lcc}
\hline & \multicolumn{2}{c}{ Awareness of hiesho } \\
& $\begin{array}{c}\text { Aware of hiesho } \\
(\mathbf{n} / \%)\end{array}$ & $\begin{array}{c}\text { Not aware of hiesho } \\
(\mathbf{n} / \%)\end{array}$ \\
\hline $\begin{array}{l}\text { Japanese }(n= \\
230)\end{array}$ & $154(67.0)$ & $76(33.0)$ \\
\hline Brazilian $(n=200)$ & $114(57.0)$ & $86(43.0)$ \\
\hline
\end{tabular}

chi-square value $=4.52 \mathrm{df}=1 \mathrm{p}=0.034$

the mean forehead temperature of Japanese women with awareness of hiesho was $36.4^{\circ} \mathrm{C}$, compared to $36.3^{\circ} \mathrm{C}$ for Brazilian women, which was not a significant difference $(p=0.28)$. The mean sole temperature of Japanese women was $31.2^{\circ} \mathrm{C}$, compared to $33.5^{\circ} \mathrm{C}$ for Brazilian women, showing a significant difference $(\mathrm{p}<0.001)$. The mean difference between forehead and sole temperatures among Japanese was $5.2^{\circ} \mathrm{C}$, significantly larger than the $2.8^{\circ} \mathrm{C}$ among Brazilians $(95 \% \mathrm{CI},-3.19$ to -1.61 ; $\mathrm{p}<0.001$ ). Average outdoor temperature at the time of the study in Brazil was $23.5^{\circ} \mathrm{C}$ and in Japan $13.3^{\circ} \mathrm{C}$.

\section{Discussion}

\section{Differences in awareness of hiesho}

It became clear that the Japanese had more awareness of hiesho than the Brazilians. Based on the preceding study, one reason for this was that hiesho caused discomfort to Japanese women, whereas Brazilian women did not feel as uncomfortable even though they were aware of hiesho $[4,10]$. Further, in terms of daily life, Brazilian women are not in the habit of using air-conditioning, whereas Japanese often spend time in air-conditioned places. In research by Miyamoto et al, it was reported that Japanese women felt cold in their extremities even in the summer, and that this was significantly higher $(\mathrm{p}<0.01)$ among those who reported awareness of hiesho, due to the effects of their living environment, such as use of air-conditioning [6]. These differences in lifestyles probably amplified the Japanese pregnant women's awareness of hiesho. Further, culturally, Japanese are said to be methodical, delicate, and highly sensitive [18]. By comparison, according to Kubota, Brazilians have more relaxed personalities and weaker awareness toward childbirth preparation [19]. These differences in national temperament or ethnicity may be one reason for differences in awareness of hiesho.

\section{Relationship between awareness of hiesho and differences in deep body temperatures}

By comparing differences between forehead and sole temperatures of subjects with awareness of hiesho, it was found that differences in deep body temperatures were reflected in awareness of hiesho among both the Brazilians and the Japanese. Therefore, this indicated that hiesho is not a condition particular to Asians; it also exists among Westerners. A comparison between Brazilians and the Japanese monitored in June and July revealed that the Brazilians had a significantly larger difference in deep body temperature. Additionally, comparing Brazilians to the Japanese monitored in November, the Japanese showed a significantly larger difference in deep body temperature compared to the Brazilians. In Brazil, the average outdoor temperature was $23.5^{\circ} \mathrm{C}$ when the women were monitored. In Japan, outdoor temperatures were $25.0^{\circ} \mathrm{C}$ in June and July, and $13.3^{\circ} \mathrm{C}$ in November. Therefore, in the comparison between Brazilians and the Japanese monitored in November, as one would expect, the reason for the significantly larger difference among the Japanese was probably the outdoor temperature lower by $10^{\circ} \mathrm{C}$.

With regard to the relationship between body temperature and outdoor temperature, Imai et al reported that on a seasonal basis, an overwhelmingly large number of Japanese women were aware of hiesho in winter (78.9\%) [20]. Arawaka and Miura found that seasonal temperature changes were experienced most strongly in the periphery and reported that peripheral temperature was lower in winter than in summer $[13,21]$. These findings also indicated that temperatures in Brazil, where the climate is sub-tropical and transitions between the seasons are less clear than in Japan, remained relatively stable year-round compared to Japan, but that differences in deep body temperatures became larger if the outdoor temperature declined. In other words, the

Table 4 Comparison of Japanese and Brazilian deep body temperature characteristics by outdoor seasonal temperature (June/July)

\begin{tabular}{|c|c|c|c|c|c|c|c|}
\hline & $\begin{array}{c}\text { Japanese }(\mathrm{n}=88) \text { June/July } \\
=25^{\circ} \mathrm{C} \\
\text { Mean }(\mathrm{SD})\end{array}$ & $\begin{array}{c}\text { Brazilian }(\mathrm{n}=114) \text { October - February } \\
=23.5^{\circ} \mathrm{C} \\
\text { Mean (SD) }\end{array}$ & $\begin{array}{c}\mathrm{t} \\
\text { value }\end{array}$ & df & $\begin{array}{c}p \\
\text { value }\end{array}$ & $\begin{array}{c}\text { mean } \\
\text { difference }\end{array}$ & $95 \% \mathrm{Cl}$ \\
\hline $\begin{array}{l}\text { Forehead } \\
\text { temperature }\left({ }^{\circ} \mathrm{C}\right)\end{array}$ & $36.4(0.30)$ & $36.3(0.33)$ & -0.25 & 200 & 0.80 & -0.01 & $\begin{array}{c}-0.10- \\
0.08\end{array}$ \\
\hline Sole temperature $\left({ }^{\circ} \mathrm{C}\right)$ & $34.4(1.67)$ & $33.5(2.68)$ & -2.88 & 191.98 & 0.004 & -0.89 & $\begin{array}{c}-1.50- \\
0.28\end{array}$ \\
\hline Difference $\left({ }^{\circ} \mathrm{C}\right)$ & $2.0(1.69)$ & $2.8(2.68)$ & 2.85 & 192.80 & 0.01 & 0.88 & $\begin{array}{l}0.27- \\
1.49\end{array}$ \\
\hline
\end{tabular}


Table 5 Comparison of Japanese and Brazilian deep body temperature characteristics by outdoor seasonal temperature (November)

\begin{tabular}{|c|c|c|c|c|c|c|c|}
\hline & $\begin{array}{c}\text { Japanese }(\mathrm{n}=66) \text { November }= \\
13.3^{\circ} \mathrm{C}\end{array}$ & $\begin{aligned} \text { Brazilian }(\mathrm{n}= & 114) \text { October-February } \\
& =23.5^{\circ} \mathrm{C}\end{aligned}$ & $\begin{array}{c}\mathrm{t} \\
\text { value }\end{array}$ & df & $\begin{array}{c}p \\
\text { value }\end{array}$ & $\begin{array}{c}\text { mean } \\
\text { difference }\end{array}$ & $95 \% \mathrm{Cl}$ \\
\hline & Mean (SD) & Mean (SD) & & & & & \\
\hline $\begin{array}{l}\text { Forehead } \\
\text { temperature }\left({ }^{\circ} \mathrm{C}\right)\end{array}$ & $36.4(0.37)$ & $36.3(0.33)$ & -1.08 & 178 & 0.28 & -0.06 & $\begin{array}{l}-0.16- \\
0.05\end{array}$ \\
\hline Sole temperature $\left({ }^{\circ} \mathrm{C}\right)$ & $31.2(2.47)$ & $33.5(2.68)$ & 5.81 & 178 & $<0.001$ & 2.34 & $\begin{array}{l}1.55- \\
3.14\end{array}$ \\
\hline Difference $\left({ }^{\circ} \mathrm{C}\right)$ & $5.2(2.40)$ & $2.8(2.68)$ & -6.01 & 178 & $<0.001$ & -2.4 & $\begin{array}{c}-3.19- \\
1.61\end{array}$ \\
\hline
\end{tabular}

comparison between the Brazilians and the Japanese with awareness of hiesho indicated that differences between forehead and sole temperatures would vary depending on outdoor temperature (season).

\section{Conclusions}

It became clear that Japanese women were more aware of hiesho than Brazilian women.

By comparing differences between core body and peripheral temperatures of pregnant women with awareness of hiesho, it was found that differences in deep body temperatures were reflected in awareness of hiesho among the Brazilians as well as the Japanese. Therefore, this indicated that hiesho is not a condition particular to Asians; it also exists among Westerners.

In addition, it was presumed that differences in deep body temperatures were affected by outdoor seasonal temperatures by comparing the differences in deep body temperatures between the Japanese monitored in June and July and the Brazilians, and between the Japanese monitored in November and the Brazilians

\footnotetext{
Acknowledgements

Heartfelt thanks are offered to the subjects who participated in this study and to the staff who were sympathetic to our research and provided us with a venue to collect data. We also wish to thank Professor Haruo Yanai, of St. Luke's College of Nursing, our advisor for this research paper. This research project was carried out under the rules of an international agreement with Brazil (Parana State official gazette registration no. 7664; the National Ethics Council registration no. Registro CONEP 14454). This research was conducted as part of a study under the Grants-in-Aid for Scientific Research (Basic Research (C), project no. 19592538) from the Japanese Ministry of Education, Culture, Sports, Science and Technology. Part of data in this paper was published in "Nakamura S. (2008) Skin temperature characteristics of pregnant women with hiesho, and their connection to daily life. Journal of Japan Academy of Nursing Science, 28, $3-$ 11." and "Nakamura S, Horiuchi S, Mori T et al.: Sensitivity To Cold Among Pregnant Women - An Analysis Of Brazilian Women -. The Japan Academy of Midwifery 2010. 24(2):205-214."

\section{Author details}

${ }^{1}$ Keio University,4411 Endo, Fujisawa, Kanagawa 252-8330, Japan. ${ }^{2}$ Nursing Department, State University of Maringa, Av. Colombo, 5790 Bloco 1, Sala 15, Maringa, Parana, Brazil. 'St. Luke's College of Nursing and St.Luke's Birth Clinic, 10-1, Akashi-cho, Chuo-ku, Tokyo 104-0044, Japan. ${ }^{4}$ Mori Birth Center, 4-13-3, Mikageishi-machi, Higashinada-ku, Kobe 658-0045, Japan. ${ }^{5}$ St. Mary's College, 422, Tsubukuhonmachi, Kurume 830-8558, Japan.
}

\section{Authors' contributions}

SN had full access to all data in the study, and took responsibility for the integrity of the data, the accuracy of the data analysis, and the decision to submit the paper for publication. SMTI and TM participated in the study design and acted as coordinators during fieldwork. SH was in charge of data analysis and acted as supervisor. MM helped draft the manuscript. All authors read and approved the final manuscript.

\section{Competing interests}

The author declares that they have no competing interests.

Received: 22 May 2011 Accepted: 5 August 2011

Published: 5 August 2011

\section{References}

1. Sakaguchi S: Concerning hiesho. Biomedical Thermology 2001, 21:60-63.

2. Miura T, Katano Y, Sumimoto K, Kanayama N: Awareness of hiesho among adult women and research into its causes. Maternal Health 2001, 4:784-789.

3. Terasawa $\mathrm{K}$ : On recognizing and treating hiesho in traditional kampoh medicine. Shoyakugaku Zasshi 1987, 41:85-96.

4. Nakamura S: Skin temperature characteristics of pregnant women with hiesho, and their connection to daily life. Journal of Japan Academy of Nursing Science 2008, 28:3-11.

5. Ishihara Y: Hiesho Causes Ailments Tokyo: Kobunsha; 2005.

6. Miyamoto N: Relationship between chilliness of the limbs and daily-life conditions in young females. Japanese Journal of Hygiene 1995, 49:1004-1012.

7. Gary FC: Williams Obstetrics. 22 edition. New York: McGraw-Hill; 2005.

8. Myles DM: Textbook for Midwives Oxford: Churchill Livingstone; 2003.

9. Nakamura S: Sensitivity to Cold: A Concept Analysis. Journal of Japan Academy of Nursing Science 2010, 30:62-71.

10. Nakamura S, Horiuchi S, Mori T, S Momoi M: Sensitivity To Cold Among Pregnant Women - An Analysis Of Brazilian Women-. The Japan Academy of Midwifery 2010, 24:205-214.

11. Iriki M: Mechanism of Body Temperature Control Tokyo: Bunkodo; 1995.

12. Tanaka K: Analysis of skin surface temperatures of pregnant women. Maternal Health 2005, 45:464-470.

13. Miura J: Pitfalls of thermography: Examination environment. The Japanese Society of Thermology 2004, 23:142-146.

14. Tsuji T: Deep body temperature measurement. BME 1988, 2:185-191.

15. Tsuji T: Deep body temperature changes in the forehead and heel and their clinical significance. Clinical Thermometry and Thermomedicine 1982, 2:71.

16. Yamazaki T: Continuous monitoring of deep body temperatures at various sites in the body using a deep body thermometer and clinical appraisals of the method. Tokyo Women's Medical University Magazine 1981, 51:1441-1445.

17. WHO:Global Database on Body Mass Index. [http://apps.who.int/bmi/ index.jsp?introPage=intro_3.html].

18. Kamijima J: How Japanese Think Tokyo: Kodansha; 1975.

19. Kubota K: Conditions in perinatal nursing at a hospital in eastern Sao Paulo. Maternal Nursing 2004, 35:146-148.

20. Imai M, Akaso K, Fukunishi H: Analysis of awareness of hiesho and its causes in adult women. Ishikawa Journal of Nursing 2007, 4:55-64. 
21. Arakawa K: Seasonal variations in body temperature adjustments and energy metabolism in young women. Japanese Journal of Biometeorology 2004, 41:4.

doi:10.1186/1756-0500-4-278

Cite this article as: Nakamura et al:: Pregnant women's awareness of

sensitivity to cold (hiesho) and body temperature observational study: A comparison of Japanese and Brazilian women. BMC Research Notes 2011 4:278.

Submit your next manuscript to BioMed Central and take full advantage of:

- Convenient online submission

- Thorough peer review

- No space constraints or color figure charges

- Immediate publication on acceptance

- Inclusion in PubMed, CAS, Scopus and Google Scholar

- Research which is freely available for redistribution

Submit your manuscript at www.biomedcentral.com/submit 